\title{
Habitat preferences among three top predators inhabiting a degraded ecosystem, the Black Sea
}

\author{
Alicia Sánchez-Cabanes ${ }^{1}$, Maja Nimak-Wood ${ }^{1}$, Nicola Harris ${ }^{1}$, Renaud de Stephanis ${ }^{2,3}$ \\ ${ }^{1}$ Marine Wildlife Department, Gardline Environmental Ltd., Endeavour House, Admiralty Road, Great Yarmouth, \\ Norfolk, NR30 3NG, UK. (ASC) (Corresponding author) E-mail: alicia.sanchez-cabanes@ gardline.com. ORCID-iD: \\ http://orcid.org/0000-0001-9018-1156 \\ (MN-W) E-mail: maja.nimak-wood@gardline.com. ORCID-iD: http://orcid.org/0000-0003-2882-3079 \\ (NH) E-mail: Nicola.harris@gardline.com. ORCID-iD: http:// orcid.org/0000-0003-0641-3159 \\ ${ }^{2}$ GEMA, Grupo de Ecología Marina Aplicada, Estación Biológica de Doñana, CSIC. C/ Americo Vespucio, s/n, 41092, \\ Isla de la Cartuja, Sevilla, Spain. \\ (RdS) E-mail: renauddestephanis@ gmail.com. ORCID-iD: http://orcid.org/0000-0003-2522-7933 \\ ${ }^{3}$ CIRCE, Cabeza de Manzaneda 3, 11390, Algeciras Spain.
}

\begin{abstract}
Summary: This study investigated whether there is evidence of widespread niche partitioning based on environmental factors in the Black Sea and tested the hypothesis that physiographic factors may be employed as predictors. It addresses poorly researched areas with good habitat potential for the only three cetacean subspecies living in this area: the Black Sea short-beaked common dolphin (Delphinus delphis spp. ponticus), the Black Sea bottlenose dolphin (Tursiops truncatus spp. ponticus) and the Black Sea harbour porpoise (Phocoena phocoena spp. relicta). Generalized additive models (GAMs) were used to analyse data collected from multiple sources. In total, 745 sightings of the three species between 1998 and 2010 throughout the Black Sea were included. The analysis found depth and sea surface temperature to be the most important variables for separating the occurrence of the three species. Common dolphins occurred mainly in deep waters and in areas where the sea surface temperature was low, bottlenose dolphins were distributed primarily in shallower and warmer waters than common dolphins, and harbour porpoises were distributed in shallower waters with lower sea surface temperature than bottlenose dolphins. This study suggests strong niche segregation among the three cetacean species. The study is also the first contribution to the basic information of cetacean species distribution and habitat preferences in the Black Sea as a whole. Knowledge of the distribution of the three dolphin species in the study area is essential to establish conservation measures for these populations.
\end{abstract}

Keywords: Black Sea; bottlenose dolphin; common dolphin; GAM; habitat preferences; harbour porpoise; niche segregation; spatial modelling.

\section{Preferencias de hábitat de tres superpredadores en el mar Negro}

Resumen: El presente trabajo analiza si existen evidencias de partición de nicho en base a factores ecológicos básicos en el mar Negro, así como si dichos factores pueden ser empleados como predictores de distribución en zonas pobremente muestreadas con respecto a las tres especies de cetáceos que habitan el área: el delfín común del mar Negro (Delphinus delphis spp. ponticus), el delfín mular del mar Negro (Tursiops truncatus spp. ponticus) y la marsopa del mar Negro (Phocoena phocoena spp. relicta). Se usaron Modelos Aditivos Generalizados (GAMs) para analizar grupos de datos provenientes de múltiples fuentes. En total fueron incluidos 745 avistamientos de las tres especies entre los años 1998 y 2000 . El análisis indica que las variables profundidad y temperatura superficial del mar fueron las más influyentes a la hora de segregar las especies espacialmente. La distribución del delfín común indicó una relación positiva con aguas más profundas y frías, mientras el delfín mular y la marsopa con aguas más superficiales y cálidas, tendiendo esta última a localizarse en aguas más frías con respecto al delfín mular. Este trabajo sugiere, por lo tanto, que existe una importante segregación de nicho entre las tres especies de cetáceos. Este análisis es la primera contribución con respecto a las preferencias de hábitat de estas tres especies para toda el área del mar Negro, siendo el conocimiento de la distribución espacial esencial a la hora de establecer medidas de conservación para sus poblaciones.

Palabras clave: delfín común; delfín mular; GAM; mar Negro; marsopa; modelos espaciales de distribución; preferencias de hábitat; segregación de nicho.

Citation/Como citar este artículo: Sánchez-Cabanes A., Nimak-Wood M., Harris N., de Stephanis R. 2017. Habitat preferences among three top predators inhabiting a degraded ecosystem, the Black Sea. Sci. Mar. 81(2): 217-227. doi: http://dx.doi.org/10.3989/scimar.04493.07A

Editor: D. Oro.

Received: June 14, 2016. Accepted: January 19, 2017. Published: March 27, 2017.

Copyright: (C) 2017 CSIC. This is an open-access article distributed under the terms of the Creative Commons Attribution (CC-by) Spain 3.0 License. 


\section{INTRODUCTION}

The Black Sea is a naturally isolated body of water in which three subspecies of cetacean can be found: the Black Sea short-beaked common dolphin (Delphinus delphis ponticus) (Barabash 1935), the Black Sea bottlenose dolphin (Tursiops truncatus ponticus) (Barabash-Nikiforov 1940) and the Black Sea harbour porpoise (Phocoena phocoena relicta) (Abel 1905). These three species are at the top of the trophic web in the basin, with no natural predators (Kleinenberg 1956, Jefferson et al. 2008).

The status of these populations has been of a great concern since the second half of the $20^{\text {th }}$ century (Smith 1982, Mikhalev 2004, Mikhalev et al. 2004). The main threat came from mass legal takes of cetaceans in commercial fishery of several riparian countries, which caused a dramatic decline of cetacean populations that brought them close to extinction (Smith 1982, Zemsky 1994, BSC 2008, Tonay and Öztürk 2012), and had a deep impact on the structure and dynamics of the ecosystem as a whole (Fontaine et al. 2012). The exact number of Black Sea cetaceans killed in the $19^{\text {th }}$ and $20^{\text {th }}$ centuries is unknown, but it has been estimated at more than five million (BSC 2008) cumulatively for all bordering countries. The dolphin harvest mainly focused on common dolphins and harbour porpoises. These activities were banned in the USSR, Bulgaria and Romania in 1966 and in Turkey in 1983 (Smith 1982, Tonay and Öztürk 2012). Nonetheless, a level of illegal catches has continued to be documented in recent years (Buckland et al. 1992, Gol'din and Gol'din 2004). This massive fishery has likely led both Black Sea harbour porpoise and bottlenose dolphin to be listed as Endangered and the Black Sea common dolphin as Vulnerable in the IUCN Red List of Threatened Species (Birkun 2008, 2012, Birkun and Franzis 2008).

Despite the ban on the cetacean fishery, the reduced populations did not recover due to prey depletion in the 1980s and early 1990s (Eremeev and Zuyev 2004). Eutrophication, increased pollutants and organic materials, and climate warming episodes, all enhanced by overfishing and the invasion of alien species (a lobate ctenophore, Mnemiopsis leidyi) had ecosystem-wide consequences and led to a four-fold reduction of the Black Sea fish landings in 1991 (Eremeev and Zuyev 2004). Commercially important species such as anchovy (Engraulis encrasicolus) and sprat (Sprattus sprattus) that play a crucial role in the Black Sea pelagic food webs (Daskalov et al. 2007) and are also cetacean main prey were dramatically decimated (Daskalov et al. 2007). Overfishing using trawling techniques and eutrophication caused a decrease in bottom oxygen content, particularly on the Northwest Shelf. This resulted in hypoxic conditions, further degrading and changing the diversity of benthic communities and reducing the dolphins' sources of food (Eremeev and Zuyev 2004, Anton et al. 2010). A certain level of recovery of some fish stocks has been recorded in the recent years but, overall, the ecosystem is out of balance as a result of decades of exploitation with no coordinated regional management, and it is unlikely that it will revert to the original state (BSC 2008, Bologa and Sava 2012). Reduced prey availability has also compromised cetacean health, increasing their susceptibility to viral infection (Birkun et al. 1999). Today, by-catch is the biggest threat for cetaceans in the Black Sea, especially for those living in the coastal waters (Tonay and Öztürk 2003, Gol'din and Gol'din 2004, Anton et al. 2010). There are indications that the annual level of harbour porpoise incidental captures may be in the thousands over the entire Black Sea (Tonay and Öztürk 2003), including incidental catches during illegal fishing practices (Öztürk 2013). Illegal, unreported and unregulated exploitation of marine biological resources is one of the major environmental, economic and social problems concerning the entire Black Sea region (Birkun et al. 2006, Öztürk 2013).

Although the three cetacean species are still under a great amount of anthropogenic pressure, the available information about their abundance, population trends and spatial distribution is limited. After the Soviet moratorium of the fishery, aerial surveys were conducted by Soviet scientists from 1967 to 1973 in the Black Sea and a joint USA-USSR shipboard survey was conducted in 1981. The first surveys provided abundance estimates by species that varied considerably from year to year and no obvious trends were identifiable (Smith 1982). The joint USA-URSS sighting cruise covered only $900 \mathrm{~km}$ of track in a small portion of the eastern Black Sea, which was insufficient to allow estimation of total abundance (Buckland et al. 1992). No final conclusions were made and the results have been criticized for a number of methodological and analytical reasons. Therefore, their use as indicators of absolute abundance is not recommended (Smith 1982, Buckland et al. 1992). In the last decade, however, local surveys have been conducted in several areas of the Black Sea in order to assess dolphin abundance and distribution (Birkun et al. 2004, Raykov and Panayotova 2012, Radu et al. 2013). Unfortunately, many studies have been published in non-peer-reviewed journals, which are not widely available, and none of these studies aim to review all the existing knowledge. Consequently, population size, distribution, and ecological factors driving the distribution of cetacean species inhabiting the Black Sea remain unknown (Bologa and Sava 2012, BSC 2008).

This study aims to assess niche segregation among the three dolphin species that inhabit the Black Sea waters and concludes with some implications of our findings for management and research. Our results show that data from a wide variety of datasets can result in robust ecological models and provide useful information on identifying possible spatial patches of preferred habitat for the three dolphin species across the Black Sea. Modelling species distribution represents a potentially powerful tool for predicting animal distribution and understanding the ecological processes determining these distributions (Redfern et al. 2006, Embling et al. 2010). Management of whale and dolphin populations can benefit from accurate, model-derived predictions of their habitat to mitigate anthropogenic effects such 
as fisheries by-catch (Kaschner et al. 2012), foresee impacts of habitat alterations on ecosystem function (D'Amico et al. 2003), protect critical habitats or select suitable areas for protection (Cañadas et al. 2005, de Stephanis et al. 2008), and aid our understanding of the ecology of these animals (Hamazaki 2002). Environmental factors can then be applied to predict marine predator distribution based on the relationships between predator, prey and environment, allowing more robust results than when one relies on prey distribution alone (Torres et al. 2008). Therefore, by assuming that the distribution of a species is non-random relative to environmental variability, predictive models of distribution typically identify the ecological relationships between the environment and species habitat selection. In this study, GAM-based spatial modelling was used in order to provide an overview of the distribution of the three cetacean species inhabiting the Black Sea in the whole basin.

\section{MATERIALS AND METHODS}

\section{Study area}

The Black Sea is one of the most isolated seas and the largest anoxic body of water in the world. The upper $100 \mathrm{~m}$ layer of water is well oxygenated, while the deep layer (100 m to $2250 \mathrm{~m}$ ) is anoxic and contains high sulphide concentrations (BSC 2008), so deep pelagic and benthic organisms are largely absent. These anoxic conditions, limited water exchange with the Mediterranean Sea, and strong inter-basin temperature and salinity contrasts render the Black Sea ecology more vulnerable to anthropogenic effects than open seas (Kideys 2002). Important features of the Black Sea are low salinity, due to high outflow of fresh water from rivers, and low water temperature, especially during the winter when the water usually freezes in the northeast (e.g. in the Sea of Azov; see UNEP 1996). The stratification is affected by the fresh water input and the Mediterranean inflow of highly saline water. The temperature shows more variation than the salinity, seasonally as well as regionally. The mean annual surface temperature varies from $16^{\circ} \mathrm{C}$ in the south to $13^{\circ} \mathrm{C}$ in the northeast and $11^{\circ} \mathrm{C}$ in the northwest (Balkas et al. 1990). Limited species exchange and lack of adaptation capability of Mediterranean species to the Black Sea maintains relatively low biodiversity. This low species diversity and absence of many local competitors has provided unoccupied ecological niches for exotic invaders and therefore made biodiversity extremely sensitive to bio-invasions (Oğuz and Oztürz 2011).

\section{Datasets}

Sighting information from a wide variety of published and unpublished sources was analysed between 1998 and 2010. The initial unpublished data set was collected by dedicated observers in the Turkish marine area of the Black Sea during an environmental and geotechnical survey. These data were collected aboard the MV L'Espoir between March and May 2010 on a survey on behalf of ExxonMobil. The second data set comprised of published data on cetacean sightings, the majority of which was collected by dedicated observers during surveys conducted in Romanian (Dede and Tonay 2010, Radu et al. 2013) Bulgarian (Raykov and Panayotova 2012), southwest Turkish (Dede and Tonay 2010) and northern and northeastern waters of the Black Sea (Birkun 2002, Gol'din and Gol'din 2004). Surveys were made from vessels, airplanes or land-based platforms. As the survey effort could not be controlled, a model using data pooled from 12 survey years (1998-2000) was built. It has been reported that when one is trying to minimize bias from unsystematic sampling associated with opportunistic data, it is likely to be more important to pool data from multiple years rather than several different areas (Moura et al. 2012). Only multispecies surveys were used in this analysis. Sightings data were digitalized from the maps presented in the publications and included in a database with Arc Map 10.0.

\section{Species distribution models}

The habitat preferences of cetaceans within the study area were investigated. The relationships between the spatial occurrence of the cetaceans and environmental variables were assessed using generalized additive modelling (GAM) techniques (Hastie and Tibshirani 1990, Hammond et al. 2013, Notarbartolo di Sciara et al. 2015). Data exploration was applied following the protocol described in Zuur et al. (2010). The opensource statistical programming language $\mathrm{R}$ version 2.6.2 (http://cran.r-project.org) and the MGCV library within $\mathrm{R}$ were used (Wood 2001). Given that the majority of the data set came from different sources, effort information was not available for most of the surveys included in this study, so a model based on presence and "pseudo-absence" was used (Esteban et al. 2013). Only studies in which multispecies information was available were chosen for the analysis. A GAM with a Tweedie distribution and logit link function were used. The parameter $\mathrm{p}$ for the Tweedie distribution used was 1.1 and the $\gamma$ (gamma) was 1.4 , as recommended by Wood (2006) to prevent over-fitting.

All the cetacean sightings were treated as "sampling stations". As only multispecies datasets were used, this approach was chosen instead of a classical absence assigned randomly (Stockwell 1999) to reduce the bias. The models were fitted with the presence dataset, including sightings of the particular species obtained by different platforms, while all other sightings were treated as "pseudo-absences". At these locations, it was assumed that an observer was performing a dedicated watch, and when other species were sighted, that particular sighting was considered as pseudo-absence for the analysed species. The general structure of the model was

$$
E\left(p_{i}\right)=\exp \left[\theta_{0}+\sum_{k} f_{k}\left(z_{i k}\right)\right]
$$




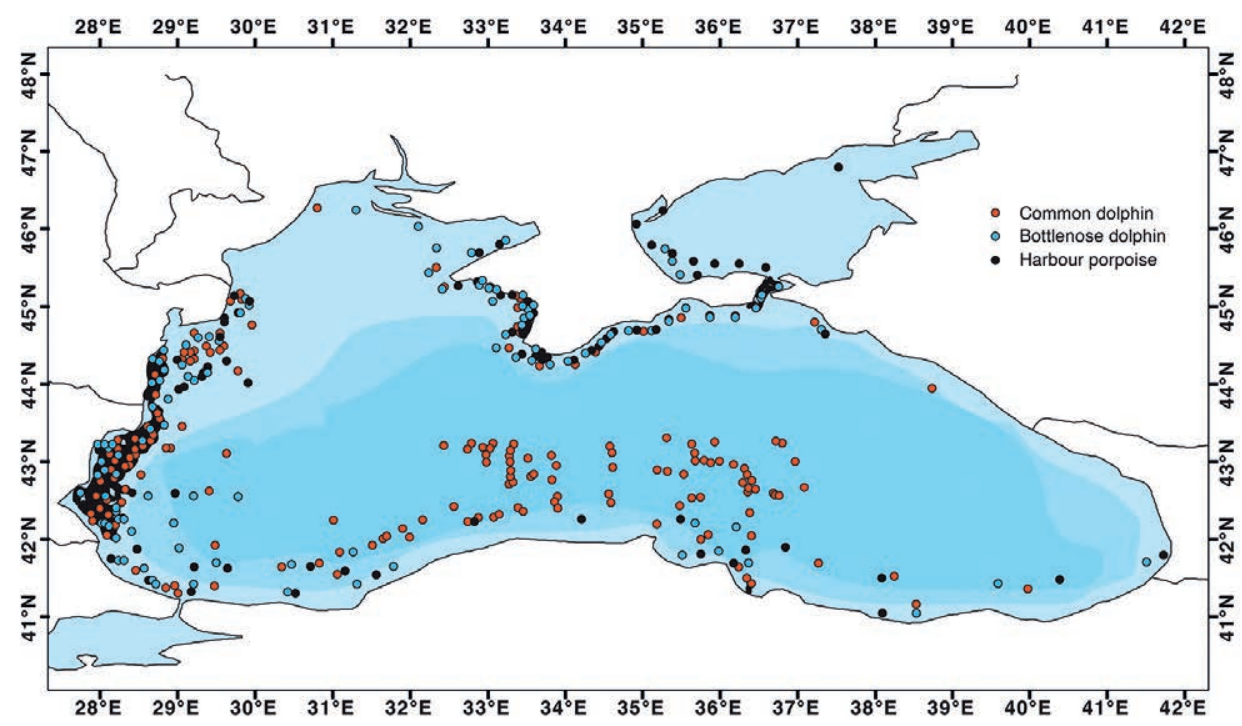

Fig. 1. - Visual sightings in the Black Sea between 1998 and 2010.

where $p_{i}$ is the probability of finding the species analysed at the $i^{\text {th }}$ sampling station, $\theta_{0}$ is the intercept, $f_{k}$ are smoothed functions of the explanatory covariates, and $z_{i k}$ is the value of the $k^{\text {th }}$ explanatory covariate at the $i^{\text {th }}$ sampling station.

The environmental variables used in this study were sea bottom depth (its log was used, named as logbat) obtained from ETOPO2 (Amante and Eakins 2009), its derivate slope and aspect (obtained with the R library SDMtools (Van der Wal et al. 2010)), distance to the coast, sea surface temperature (SST) and chlorophyll $a$ concentration, obtained from satellite images of MODIS (Carder et al. 2003) when month and year information were available. In order to evaluate a possible temporal variation, all models included year as covariate. Type of platform was also included in the models as a candidate covariate to minimize bias of the sampling method.

\section{Model selection}

A forward stepwise model selection was followed. All covariates were evaluated individually and chosen by a) the probability that each variable was included in the model by chance (less than 0.01 ), b) the generalized cross validation score (an approximation to the Aikake information criterion-the best model was the one with lowest value), and c) the percentage of deviance explained. The number of candidate environmental covariates in a spatial modelling framework is potentially large, so variables of direct relevance to cetaceans were included. Based on these criteria, the best model was selected for the given species (see Table 2).

\section{Environmental predictive models}

The best GAM models were used to generate predicted probability values of presence ( 0 to 1$)$ on a grid of $2 \times 2 \mathrm{~km}$ in the study area, which were plotted using ArcMap 10.0. In order to obtain the coefficient of variation for the predictions and thus to optimize the pre- dictive model accuracy, 200 bootstraps with replacement were run for each model, and a prediction grid was obtained for each bootstrap iteration. Coefficient of variations $(\mathrm{CV})$ per-cell were estimated and plotted in Figure 3. Models were evaluated through CV. To make predictions over the entire Black Sea area, it was necessary to select values for the temporally varying covariates. The predictive values from the GAM analysis were used to construct presence probability distribution maps for the three cetacean species. This model was then projected to the entire Black Sea. The summer season was selected (mean of July-August 2008-2009) because the majority of the observations were made during this time. This was presented as an example to avoid annual and month variability.

\section{RESULTS}

\section{Survey observations}

A total of 745 visual sightings of three species of cetaceans were obtained from surveys conducted between 1998 and 2010. There were 242 observations of Black Sea common dolphin (Delphinus delphis ponticus), 302 of Black Sea bottlenose dolphin (Tursiops truncatus ponticus) and 201 of Black Sea harbour porpoise (Phocoena phocoena relicta) (Fig. 1).

\section{Models}

Log-transformed depth (logbat) and SST were the most significant environmental predictors for all three Black Sea species: common dolphin, bottlenose dolphin and harbour porpoise. Statistical values for each species are shown in Table 1 . Both were highly significant and explained $35.4 \%, 33.6 \%$ and $22.7 \%$, of the deviance, respectively (Table 2 ). Presence probability of common dolphins was higher in water depths of more than $50 \mathrm{~m}$ (towards deepest waters), and towards cooler waters, between 5 and $18^{\circ} \mathrm{C}$ (Fig. $2 \mathrm{~A}, \mathrm{~B}$ ). Bottlenose dolphin presence was expected in waters below 
Table 1. - Mean (with standard deviation) and ranges (min-max) for Black Sea common dolphin (Delphinus delphis ponticus), Black Sea bottlenose dolphin (Tursiops truncatus ponticus) and Black Sea harbour porpoise (Phocoena phocoena relicta) covariates shown to be significant.

\begin{tabular}{|c|c|c|c|c|}
\hline \multirow{3}{*}{$\begin{array}{l}\text { Statistic } \\
\text { BAT (m) }\end{array}$} & \multicolumn{2}{|c|}{ Delphinus delphis ponticus } & \multirow{3}{*}{$\begin{array}{c}\text { Tursiops truncatus ponticus } \\
135.39(345.45) \\
1-2170\end{array}$} & \multirow{3}{*}{$\begin{array}{c}\text { Phocoena phocoena relicta } \\
192.43(407.18) \\
1-2272\end{array}$} \\
\hline & Mean & $918.72(1000.22)$ & & \\
\hline & Range & $5-2437$ & & \\
\hline \multirow[b]{2}{*}{$\operatorname{SST}\left({ }^{\circ} \mathrm{C}\right)$} & Mean & $13.9 \pm 4.68$ & $19.4 \pm 4.4$ & $17.0 \pm 5.55$ \\
\hline & Range & 7.4-24.4 & $5.9-24.5$ & $5.2-24.4$ \\
\hline
\end{tabular}

\section{A}

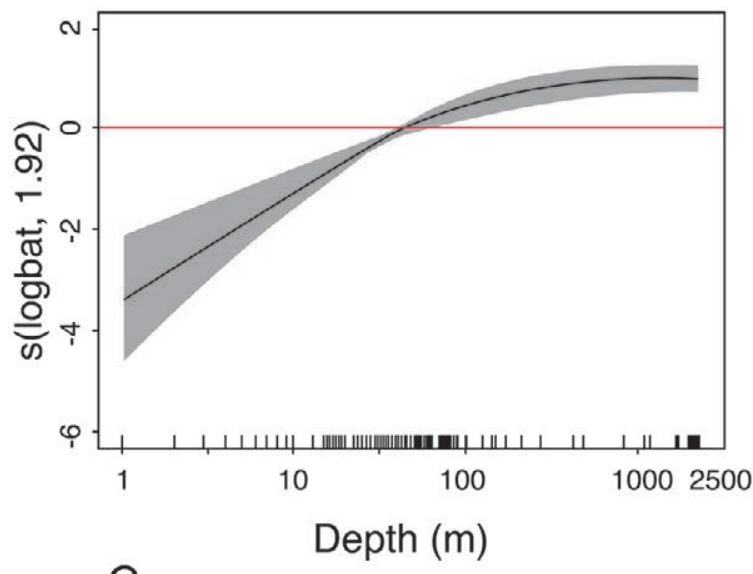

C

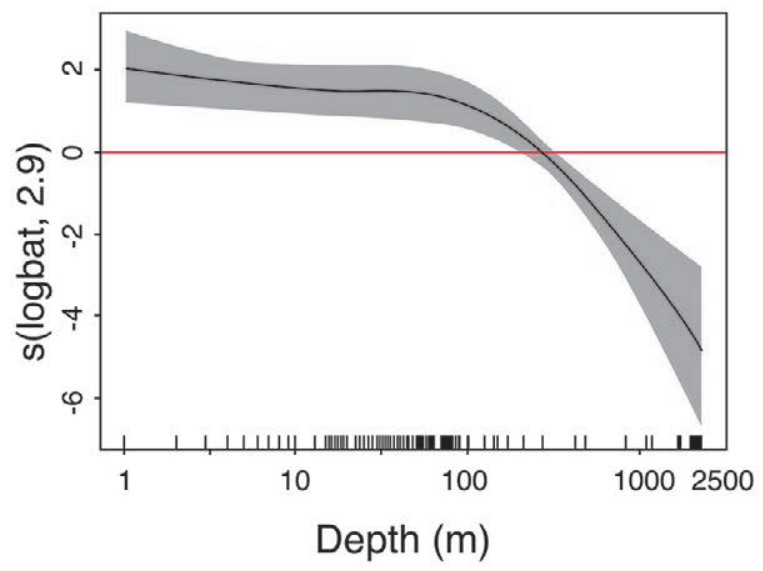

$\mathrm{E}$

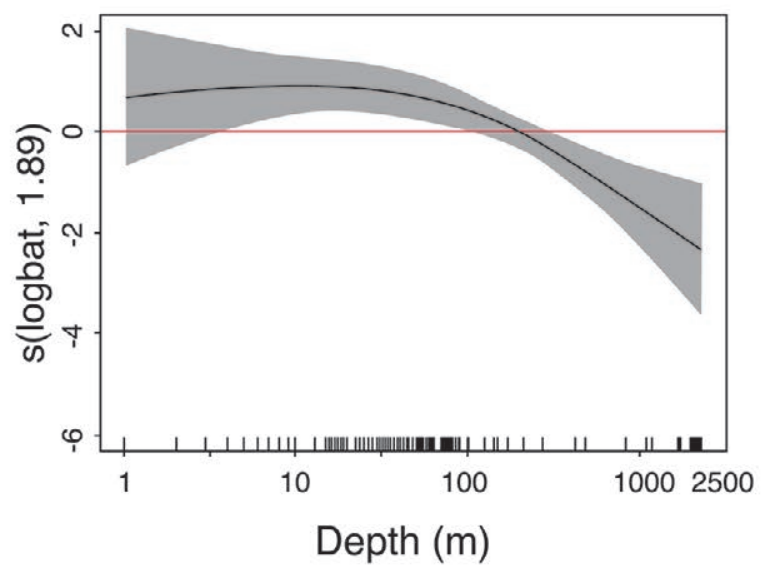

B

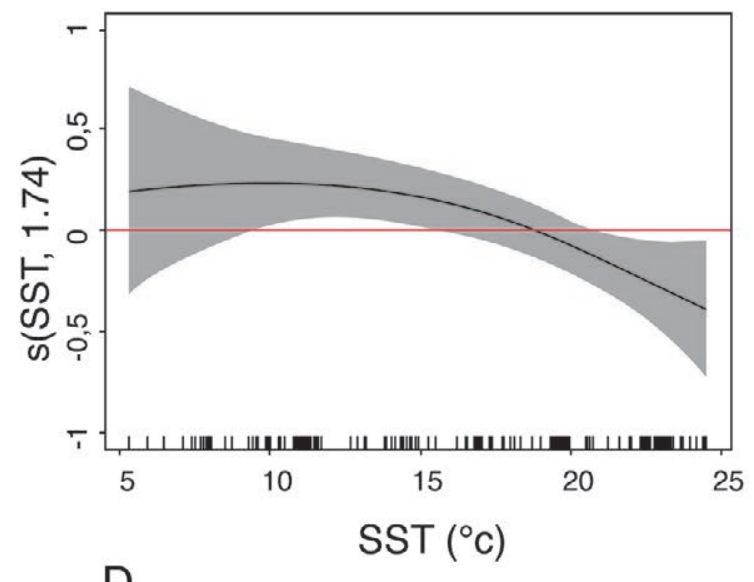

D

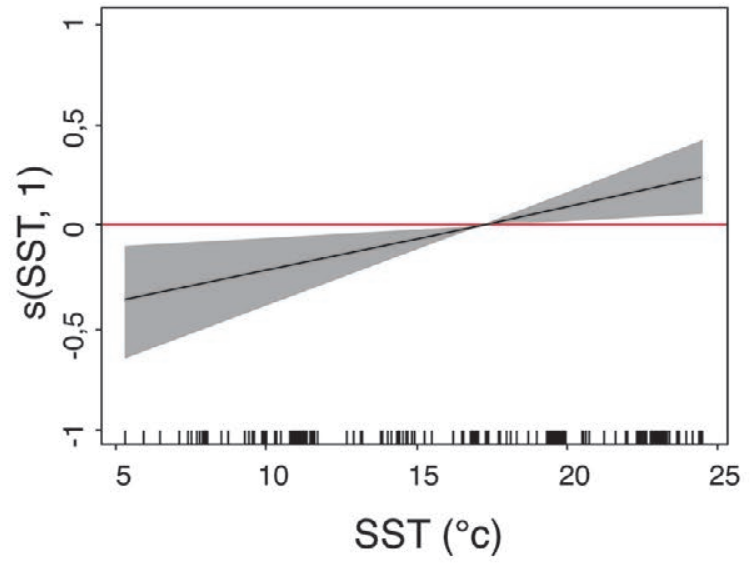

$\mathrm{F}$

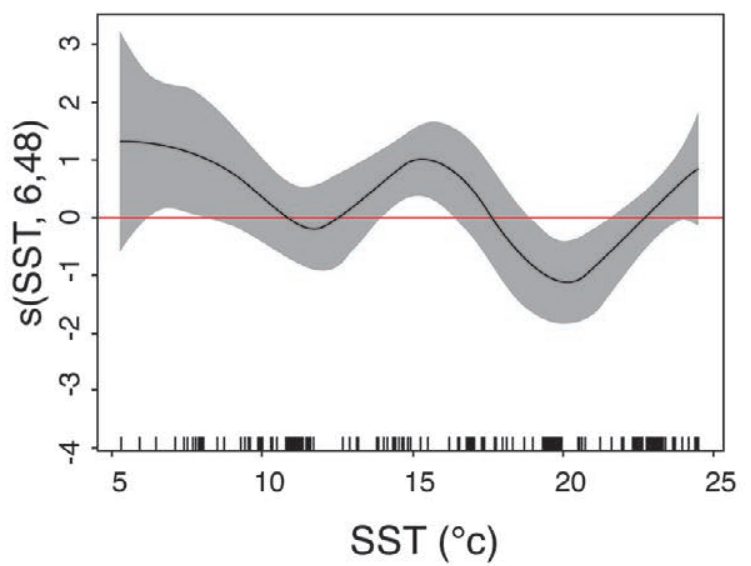

Fig. 2. - Relationships between observations of Black Sea common dolphin (Delphinus delphis ponticus) and (A) depth, (B) sea surface temperature (SST); between observations of Black Sea bottlenose dolphin (Tursiops truncatus ponticus) and (C) depth and (D) sea surface temperature (SST); and between observations of Black Sea harbour porpoise (Phocoena phocoena relicta) and (E) depth and (F) sea surface temperature (SST). Smooths are shown with the number of degrees of freedom in parentheses. Solid lines show the smooth estimate and grey areas the estimated $95 \%$ point-wise confidence intervals for the smoother. The zero line on the Y-axis is the mean of Y estimated by the model. The small vertical lines at the bottom of the graphs show the values at which there are observations. 
Table 2. - Evaluation of different models for Black Sea common dolphin (Delphinus delphis ponticus), Black Sea bottlenose dolphin (Tursiops truncatus ponticus) and Black Sea harbour porpoise (Phocoena phocoena relicta). Sea surface temperature (SST), log-transformed depth (logbat), distance to coast (disthd), generalized cross validation score (GCV), difference between GCV score $(\triangle \mathrm{GCV})$, deviance explained by the model (\%Dev) and degrees of freedom (df). Only covariates showing a significant relati onship are shown.

\begin{tabular}{lcccc}
\hline Covariates & GCV & $\Delta \mathrm{GCV}$ & $\% \mathrm{Dev}$ & $\mathrm{df}$ \\
\hline Delphinus delphis ponticus & & & & \\
SST+logbat & 0.560 & 0 & $35.4 \%$ & 4.67 \\
disthd+SST & 0.618 & 0.058 & $29.1 \%$ & 5.77 \\
disthd & 0.675 & 0.115 & $21.6 \%$ & 2.97 \\
SST & 0.694 & 0.134 & $19.5 \%$ & 3.57 \\
logbat & 0.708 & 0.147 & $17.8 \%$ & 2 \\
Tursiops truncatus ponticus & & & \\
SST+logbat & 0.583 & 0 & $33.6 \%$ & 4.9 \\
disthd+SST & 0.633 & 0.049 & $29.2 \%$ & 8.26 \\
SST & 0.752 & 0.169 & $12.9 \%$ & 2 \\
disthd & 0.776 & 0.192 & $10.1 \%$ & 3.19 \\
logbat & 0.790 & 0.206 & $8.7 \%$ & 3.91 \\
Phocoena phocoena relicta & 0.531 & 0 & $22.7 \%$ & 9.37 \\
SST+logbat & 0.583 & 0.052 & $14.7 \%$ & 8.78 \\
SST & 0.612 & 0.081 & $9.8 \%$ & 7.24 \\
disthd+SST & 0.797 & 0.266 & $4.6 \%$ & 2.01 \\
logbat & 0.797 & 0.263 & $5.2 \%$ & 4.6 \\
disthd & & & & \\
\hline
\end{tabular}

$250 \mathrm{~m}$ depth (towards the mainland), with a higher preference for waters with SST between 18 and $24^{\circ} \mathrm{C}$ (Fig. 2C, D). Higher presence probability of harbour porpoises was predicted in water shallower than 200 $\mathrm{m}$ depth (towards the mainland) and SST below $18^{\circ} \mathrm{C}$ (Fig. 2E, F). No relationships were found between year or type of platform and any species of this study.

\section{Model predictions of distribution}

Prediction maps show a large area of presence probability of common dolphin in the centre of the basin, extending widely across the area (Fig. 3A). Bottlenose dolphin and harbour porpoise prediction maps show the highest presence probability in shallow waters, towards the mainland, the Northwest Shelf and the Sea of Azov (Fig. 3B, C).

\section{DISCUSSION}

This study provides a novel approach in studying the distribution of the top three predator species in the Black Sea. The kinds of datasets we used are statistically difficult to investigate due to the different surveying conditions and the lack of data related to observation effort. Therefore, no attempt is made to provide relative abundance estimations, as this study does not provide a framework for estimating detection functions. However, sightings of all the three species were enough to assess whether there is niche segregation, providing a measure of the species' distribution patches, as well as the habitat preferences relative to the other species recorded in the study area. Due to the high number of sightings of the three dolphin species in the study area, our "pseudo-absence" approach has been previously considered suitable for solving the heterogeneity of effort from different datasets by using other dolphins' presence as proxy for the given dolphin species' absence (Esteban et al. 2013).

Black Sea cetacean distribution and abundance has often been related to the patterns of fish migration and aggregations (Mikhalev et al. 2004, Dede and Tonay 2010, Raykov and Panayotova 2012), which depend on seasonal water temperatures along with other abiotic factors (BSC 2008). Distribution estimates can be highly uncertain for species that live in a dynamic environment and have complex behaviour and life histories (Isojunno et al. 2012). Although they can often be related to physical oceanographic features such as water depth, it is likely that prey abundance and movements are the most important factors in determining the occurrence and movements of cetaceans (Gaskin 1982, Evans 1987, Nøttestad et al. 2014). Oceanographic features have therefore been widely used as proxies of ecological variables such as prey distribution, which is difficult to obtain or cannot be measured (Torres et al. 2008). Different circulation features, bathymetric complexity, physico-chemical and strong weather patterns are known to exist within the study area and are well documented (Oğuz et al. 1995, BSC 2008). These com-
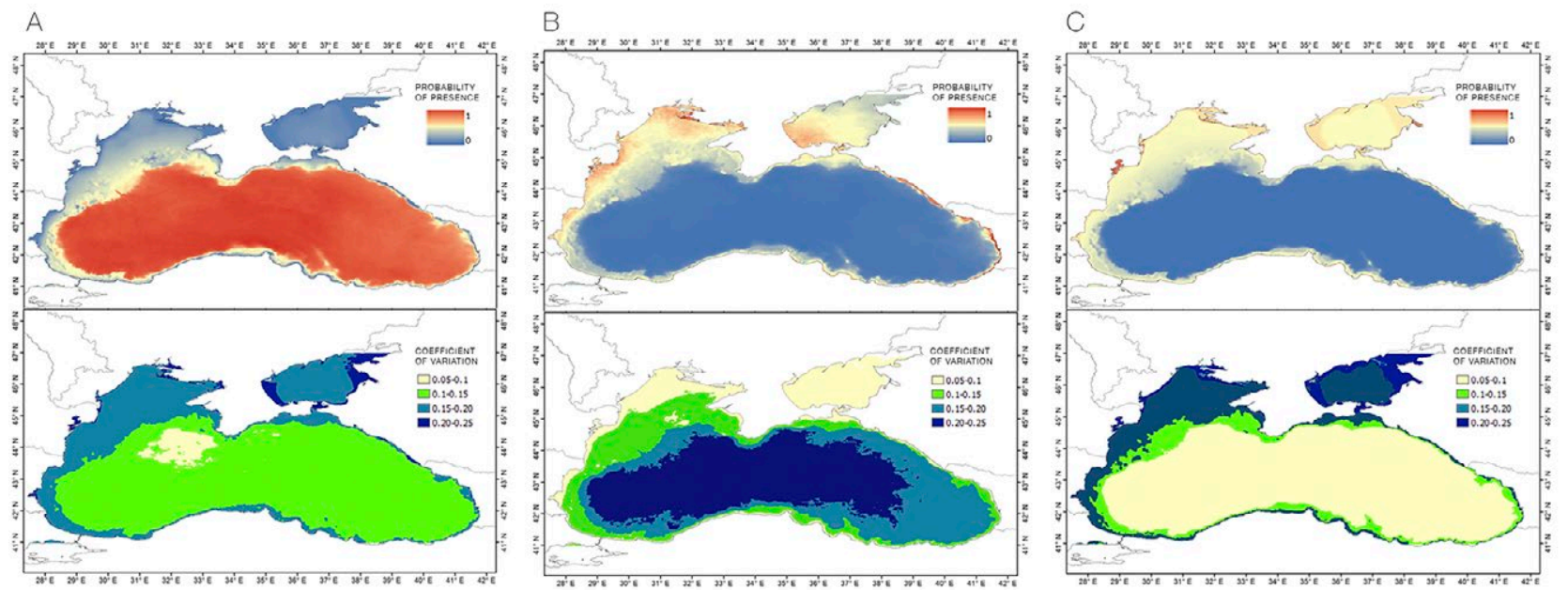

Fig. 3. - Spatial prediction pattern of coefficient of variation of the prediction models after 200 bootstrap resamples for (A) Black Sea common dolphin (Delphinus delphis ponticus), (B) Black Sea bottlenose dolphin (Tursiops truncatus ponticus) and (C) Black Sea harbour porpoise (Phocoena phocoena relicta) probabilities during the summer season of 2008-2009. 
plex oceanographic features could limit the possibility of identifying such a proxy. Nonetheless, the models have highlighted significant relationships between bathymetry and SST and the distribution of common dolphin, bottlenose dolphin and harbour porpoise, suggesting that habitat use is partitioned among the three cetacean species in relation to these features. Spatial modelling approaches demonstrated in this study were also able to predict species occurrence at high levels of statistical significance for each species tested.

Worldwide, short-beaked common dolphins occur in temperate waters in a wide range of habitats, both over the continental shelves and in deep oceanic regions (e.g. Au and Perryman 1985, Forcada et al. 1990, Ferrero and Walker 1995). The short-beaked common dolphin is one of the most common cetacean species in Mediterranean Sea (Bearzi et al. 2003) and is found in both pelagic and neritic environments (Notarbartolo di Sciara et al. 1993, Cañadas et al. 2002). According to the results of this study, Black Sea common dolphins seem to be more likely to be associated with greater depths (range 50 to $2250 \mathrm{~m}$ ). Temperature appeared to be another important predictor, with a higher preference towards cooler waters $\left(5-18^{\circ} \mathrm{C}\right)$ of the basin. Moreover, these results compare closely with previous studies in the area that have shown that Black Sea common dolphins are widely spread across whole basin, but encountered predominantly in the deep offshore waters throughout the Black Sea (Kleinenberg 1956, Raykov and Panayotova 2012, Radu et al. 2013). Depth and SST have been considered as good predictors of distribution and abundance in previous studies of habitat preferences for short-beaked common dolphins (Forney 2000, Cañadas et al. 2005, Cañadas and Vázquez 2014). In a modelling exercise carried out for multispecies in Mediterranean and Atlantic Spanish waters, a higher preference for areas with a lower temporal variability in average SST and cooler waters than the overall average was observed (Cañadas et al. 2005). This is consistent with this approach, as SST variability across the Black Sea basin seems to be lower throughout the south and towards offshore waters, away from the northwestern and coastal shelves (Ozsoy and Unluata 1997, Shapiro et al. 2010), where less probability of presence for common dolphins was detected in this study (Fig. 3A). In the western Atlantic however, most areas of common dolphin distribution coincide with moderate to strong upwelling and common dolphins appear to avoid warm waters (Jefferson et al. 2009). Highly productive areas have also been reported in other areas to be the preferred habitat of this species (Reilly 1990, Fiedler and Reilly 1994, Cañadas and Hammond 2008). A review of satellite data in the Black Sea indicates persistent upwelling in summer towards the Turkish coast (see Ozsoy and Unluata 1997), where our prediction map for the species in summer shows the higher probability of occurrence (Fig. 3A). Additionally, in the Black Sea common dolphins feed on pelagic fish (Bushuev 2002, Dede and Tonay 2010, Radu et al. 2013), which are the main prey for shortbeaked common dolphins elsewhere (Young and Cockcroft 1994, Kenney et al. 1995, Santos et al. 1996), and their distribution has also been repeatedly related to fish migrations (Bushuev 2002, Dede and Tonay 2010, Radu et al. 2013), as has been reported in other areas of the world (Young and Cockcroft 1994, Evans 1980). The present results can also be related to the pattern of fish aggregations. Ecological features, changes in fish stocks and migration patterns of commercial fish have been studied by several authors (Chashchin 1996, Daskalov 2003, Radu et al. 2011). For example, it has been found that most catches come from areas with water temperature between 10 and $14^{\circ} \mathrm{C}$ (Agirbas et al. 2010), and the highest abundance of fish eggs and larvae during spawning season in Turkish waters was found to be between 10 and $25^{\circ} \mathrm{C}$ (Satilmis et al. 2003, Şahin and Hacimurtazaoğlu 2013). In the Istanbul Strait, fish migration was found to occur between 13 and $22^{\circ} \mathrm{C}$ (Öztürk et al. 2006). Given that these temperature ranges fall within the range of temperatures that predict common dolphin distribution, interaction between these dolphins and fisheries resulting in bycatch is not surprising.

Bottlenose dolphins are among the best known and widespread of the small cetaceans, occurring in nearly all tropical and temperate seas and occupying a variety of marine habitats, from shallow coastal areas to deep seas, as well as inshore lagoons and estuaries (Leatherwood and Reeves 1990). In this study, Black Sea bottlenose dolphin occurrence was predicted to be more likely at depths below $250 \mathrm{~m}$ and in warmer waters ranging between 18 and $24^{\circ} \mathrm{C}$. Variation in the occurrence of specific behaviours in bottlenose dolphins has been documented with respect to a wide bathymetry range and environmental heterogeneity (Cañadas et al. 2005, Ingram et al. 2002) and has been related to feeding behaviour in previous studies (Hastie et al. 2004). In the Black Sea, it has been also suggested that bottlenose dolphin distribution is linked to their feeding preferences for predominantly benthic and nearshore pelagic fish (Mikhalev 2004, Birkun 2012, Gladilina and Gol'din 2014). It has been reported that in the Black Sea bottlenose dolphin may dive to depths of 90 to $100 \mathrm{~m}$ (Radu et al. 2013), though they are capable of diving much deeper than that (Leatherwood and Reeves 1990). This could be a result of a lack of prey in the deep-sea anoxic zone (Birkun 2002). In support of our results, Black Sea bottlenose dolphins have also been known to be present primarily in the littoral zone of the western-central coast of Turkey, and the northwestern Black Sea, where the continental shelf extends $250 \mathrm{~km}$ offshore (Kleinenberg 1956, Öztürk and Öztürk 2002). The smaller body size and larger skull of the Black Sea population compared with the Mediterranean and Atlantic populations could be interpreted as an adaptation to coastal environments. Similar morphological adaptations have been suggested for coastal bottlenose dolphins from the western Atlantic (Leatherwood and Reeves 1990). The limited information for deep offshore waters revealed no sightings of bottlenose dolphins, so the model prediction shows very low, or even zero probability of encountering bottlenose dolphins in the deep central waters of the Black Sea. In contrast, aerial surveys performed by the USSR in the 1960s and 
1970s have recorded bottlenose dolphins in the deep central part of the basin. Considering the changes to the marine ecosystem in the last few decades, it is suspected that the distribution, migrations, abundance and spawning areas of fish stock in the Black Sea will have been affected at a significant level (Bat et al. 2007, ahin and Hacimurtazaoğlu 2013). It is not unrealistic to suggest that the diet of bottlenose dolphins could have been more focused on pelagic fish prior to the fishery collapse in the 1980 s and early 1990 s than is currently the case. In support of this, bottlenose dolphins are considered to be opportunistic feeders that adapt their feeding habits to the availability of the most abundant prey species and thus respond to changes in their environment (Klinowska 1991, Jefferson et al. 2008). Changes in prey preferences of bottlenose dolphins in the Black Sea due to the decline among some demersal fish populations have also been suggested by Gladilina and Gol'din (2014). The authors also reported a more diverse diet in their sample. The diversity is comparable with the data from all the Mediterranean Sea (Miokovic et al. 1999, Blanco et al. 2001, Bearzi et al. 2005) or from the northeast Atlantic (Santos et al. 2007a). Such a wide diet range (a wide variety of schooling pelagic fish, benthic fish and cephalopods) is normal for the bottlenose dolphin (Santos et al. 2007b), but it has not been observed previously in the Black Sea. The central, deep waters need to be further surveyed to improve the model predictions and confirm whether the lack of bottlenose dolphins in deep waters in this study is due to the low effort of this study or to other ecological changes.

Harbour porpoise cover relatively continuously cold coastal waters of the North Pacific and the North Atlantic, around the UK and Ireland in their entirety, and south along the African coast to Senegal (Reid et al. 2003). The harbour porpoise has been found in the Aegean Sea (in the far eastern Mediterranean) and the western Mediterranean Sea (see Cañadas et al. 2005), but is absent in the rest of the Mediterranean basin (Frantzis et al. 2001). The predictive model for Black Sea harbour porpoises showed a higher preference for shallower waters than $200 \mathrm{~m}$, similar to that of bottlenose dolphins. However, the results for the SST preference were different to those of bottlenose dolphin, indicating a preference for lower water temperatures (below $18^{\circ} \mathrm{C}$ ). Depth also seems to be a significant predictor of harbour porpoise distribution (Watts and Gaskin 1985, Read and Westgate 1997, Raum-Suryan and Harvey 1998), pointing to a habitat preference for predominantly shelf waters between 50 to $150 \mathrm{~m}$, with a lower preference for waters deeper than $100 \mathrm{~m}$ (Carretta et al. 2001, Embling et al. 2010). These results are consistent with the those of the literature, which have reported that harbour porpoises occur throughout the entire basin, including the Sea of Azov, Turkish Strait systems and across the shelf in shallow waters (Mikhalev 2004, Krivokhizhin and Birkun 2006, Tonay et al. 2007). This finding may be explained by the likely feeding habits of the harbour porpoise, which targets benthic fish such as whiting and gobies, which occur in shallow waters, and pelagic schooling fishes such as sprat and anchovy, which occur in both shallow and deep waters of the basin (Mikhalev 2004, Krivokhizhin and Birkun 2006, Tonay et al. 2007). In support of the results of this study in the Black Sea, Raykov and Panayotova (2012), who conducted a study in the Bulgarian coastal zone, noted that the bulk of observed cetaceans, including the harbour porpoise, which were observed between 50 and $100 \mathrm{~m}$ isobaths, are related to the highest catch of sprat per unit area.

The present study focuses on the influence of environmental factors in the whole basin over 12 years. The results of this study show robust evidence of niche partitioning among the three species. Depth and surface temperature appeared to have been good predictors for the distributions of the three species in the area, indicating a strong trend for bottlenose dolphins and harbour porpoises to be present in shallow waters across the shelf area, with the latter showing a higher preference for cooler waters than the former. Common dolphins appear to occur predominantly offshore throughout the Black Sea basin, in the colder water range. Further studies should focus on refining habitat predictions and examining relationships between the Black Sea cetacean distribution and environmental factors and niche segregation, especially in areas such as the central and southeast coast of the basin, where there is limited information available. The use of a long time-series of data would also minimize the likelihood of false correlations in the predictions, as there is a risk with short-time-interval window ('snapshot') studies for highly mobile species such as cetaceans (Cañadas et al. 2005). Studies comparing historic data sets (Smith 1982, Buckland et al. 1992) from decades ago with current data should also be conducted in order to provide a better knowledge of possible changes to cetacean population distributions due to the environmental changes that occurred in the Black Sea. In addition, potential competition between these species may be also be influencing their habitat preferences and the differentiation of their distributions could tend to reduce it. This study provides an important contribution to the basic knowledge on cetaceans in the Black Sea as a whole, assessing the presence of the three species in areas where data are not available or inexistent.

The Black Sea environment has improved slightly over the last decade (Kideys 2002), most probably associated with the deterioration of the economic situation in the countries along the Black Sea coast (Kuznetsov 2004). However, the whole ecosystem is different from that documented in the 1960s, and the composition and structure of the marine communities are constantly changing with the decline of certain species and the expansion of others (Zaitsev and Mamaev 1997). The quality of the Black Sea ecosystem is dependent, in particular, on the survival and welfare of these top predator populations, whether or not they are unique as subspecies, because they regulate the demography of species at lower trophic levels through a top-down regulation of the trophic food-web (Daskalov et al. 2007, Fontaine et al. 2012). The poor situation of these apex predators in the Black Sea ecosystem is still of major concern (Zaitsev and Mamaev 1997). Popula- 
tions of small cetaceans are unlikely to have recovered significantly since the dolphin and porpoise fishery ban in 1983; in fact, the number of harbour porpoises is dropping (Fontaine et al. 2012, Radu et al. 2013). Despite the conservation effort in the last decade, including adoption of two essential instruments in 1996, the Agreement on the Conservation of Cetaceans of the Black Sea, Mediterranean Sea and Contiguous Atlantic Area (ACCOBAMS) and the Strategic Action Plan for the Rehabilitation and Protection of the Black Sea (BS SAP), there is still insufficient scientific information about cetacean ecology and it is widely acknowledged that this is the main obstacle in the way of their conservation (BSC 2008, Bologa and Sava 2012). A coordinated conservation effort between all the countries bordering the Black Sea is urgently required in to order to preserve this unique marine ecosystem and its unique vulnerable cetacean populations.

\section{ACKNOWLEDGEMENTS}

This study was funded by Gardline Environmental Ltd. De Stephanis was supported by the Spanish Ministry of Economy and Competitiveness ("Consejo Superior de Investigaciones Científicas"). We would like to thank Dr Isaksen of ExxonMobil for his support and encouragement to publish this study and his approval to use the data set collected during a survey conducted on behalf of ExxonMobil in the Black Sea. Many thanks to all field observers: Maja Nimak-Wood and Ryan Irvine and the crew of the L'Espoir. Drafts of this paper were improved by Belen Roldán Franco, Amy Boaden, Stiofán Ó'Ruairc and Emma Hayes, who all offered very helpful support in various ways. Finally, we would also like to thank two anonymous reviewers for their comments and suggestions on earlier drafts of the manuscript.

\section{REFERENCES}

Abel O. 1905. Eine Stammtype der Delphiniden aus dem Miocän der Halbinsel Taman. Jahrbuch der Kaiserlich-Königlichen Geologischen Reichsanstalt. Jahrb. der Kais. Geol. Reichsanstalt. 55: $375-392$.

Agirbas E., Seyhan K., Kasapoglu N. et al. 2010. Recent changes of the Turkish anchovy fishery in the Black Sea with special reference to climate change. J. Environ. Prot. Ecol. 11: 1495-1503.

Amante C., Eakins B. 2009. ETOPO1 1 Arc-minute global relief model: procedures, data sources and analysis.

Anton E., Nicolaev S., Radu G., et al. 2010. Fisheries impact on dolphin populations in the Black Sea Romanian sector. Cercet Mar. Rech. Mar. 39: 281-292.

Au D.W.K., Perryman W.L. 1985. Dolphin habitats in the eastern tropical Pacific. Fish. Bull. 83: 623-643.

Balkas T., Decev G., Mihnea R., et al. 1990. State of the Marine Environment in the Black Sea Region. UNEP, Regional Seas Reports and Studies, No:124. UNEP, Nairobi, $40 \mathrm{pp}$.

Barabash I.I. 1935. Delphinus delphis ponticus subsp. Bull Mosk Obs Ispyt Prir (Bulletin Moscow Soc Nat New Ser 44: 246-249 (In Russian with English summary).

Barabash-Nikiforov I.I. 1940. Cetacean fauna of the Black Sea. Its composition and origin. Voronezh University Publ., Voronezh, 86 pp. (in Russian).

Bat L., Şahin F., Satılmış H.H., et al. 2007. The changed ecosystem of the Black Sea and its impact on anchovy fisheries. J. FishSci. com 1: 191-226.

Bearzi G., Reeves R.R., Notarbartolo-Di-Sciara G., et al. 2003. Ecology, status and conservation of short-beaked common dolphins Delphinus delphis in the Mediterranean Sea. Mamm. Rev. 33: 224-252.

https://doi.org/10.1046/j.1365-2907.2003.00032.x

Bearzi G., Politi E., Agazzi S. et al. 2005. Occurrence and present status of coastal dolphins (Delphinus delphis and Tursiops truncatus) in the eastern Ionian Sea. Aquat. Conserv. Mar. Freshw. Ecosyst. 15: 243-257. https://doi.org/10.1002/aqc.667

Birkun A.J. 2002. The current status of bottlenose dolphins in the Black Sea. ACCOBAMS. AC18 Inf. 2, Monaco, 28 pp.

Birkun A.J. 2008. Delphinus delphis ssp. ponticus. In: IUCN 2013. IUCN Red List of Threatened Species. Version 2013.2. Downloaded on 19 April 2014. www.iucnredlist.org

Birkun A.J. 2012. Tursiops truncatus ssp. ponticus. In: IUCN 2013. IUCN Red List of Threatened Species. Version 2013.2. Downloaded on 21 April 2014. www.iucnredlist.org

Birkun A.J., Frantzis A. 2008. Phocoena phocoena ssp. relicta. In: IUCN 2013. IUCN Red List of Threatened Species. Version 2013.2. Downloaded on 21 April 2014. www.iucnredlist.org

Birkun A.J., Kuiken T., Krivokhizhin S., et al. 1999. Epizootic of morbilliviral disease in common dolphins (Delphinus delphis ponticus) from the Black Sea. Vet. Res. 144: 85-92. https://doi.org/10.1136/vr.144.4.85

Birkun A.J., Krivokhizhin S.V., Glazov D.M., et al. 2004. Abundance estimates of cetaceans in coastal waters of the northern Black Sea: results of boat surveys in August-October 2003. In: Belkovich V.M. (ed.) Marine Mammals of the Holartic, Collection of Scientific Papers. KMK Scientific Press, Moscow, pp. 64-71.

Birkun A.J., Cañadas A., Donovan G., et al. 2006. Conservation Plan for Black Sea Cetaceans. ACCOBAMS, 50 pp.

Blanco C., Salomon O., Raga J.A. 2001. Diet of the bottlenose dolphin (Tursiops truncatus) in the western Mediterranean Sea. J. Mar. Biol. Assoc. UK 81: 1053-1058. https://doi.org/10.1017/S0025315401005057

Bologa A.S., Sava D. 2012. Present state and evolution trends of biodiversity in the Black Sea: decline and restoration. J. Black Sea/Mediterranean Environ. 18: 144-154

BSC. 2008. State of the Environment of the Black Sea (2001 2006/7). In Oğuz T. (ed.). Publications of the Commission on the Protection of the Black Sea Against Pollution (BSC) 20083, Istambul, Turkey.

Buckland S.T., Smith T.D., Cattanach K.L. 1992. Status of small cetacean populations in the Black Sea: Review of current information and suggestions for future research. In: Report Of The International Whaling Commission. The International Whaling Commission, pp. 513-516.

Bushuev S.G. 2002. Principal results of the aerial observations of the Black Sea dolphins in 1970s-80s. In: Belkovich V.M. (ed.) Marine Mammals of the Holartic. Second International Conference. KMK, Baikal, Russia, pp. 60-61.

Cañadas A., Hammond P.S. 2008. Abundance and habitat preferences of the short-beaked common dolphin (Delphinus delphis) in the South-western Mediterranean: implications for conservation. Endangered Species Res. 4: 309-331. https://doi.org/10.3354/esr00073

Cañadas A., Vázquez J.A. 2014. Conserving Cuvier's beaked whales in the Alboran Sea (SW Mediterranean): Identification of high density areas to be avoided by intense man-made sound. Biol. Conserv. 178: 155-162. https://doi.org/10.1016/j.biocon.2014.07.018

Cañadas A., Sagarminaga R., García-Tiscar S. 2002. Cetacean distribution related with depth and slope in the Mediterranean waters off southern Spain. Deep Sea Res. I, 49: 2053-2073. https://doi.org/10.1016/S0967-0637(02)00123-1

Cañadas A., Sagarminaga R., De Stephanis R., et al. 2005. Habitat selection modelling as a conservation tool: proposals for marine protected areas for cetaceans in southern Spanish waters. Aquat. Conserv. 15: 495-521. https://doi.org/10.1002/agc. 689

Carder K., Chen F., Lee Z., et al. 2003. MODIS Ocean Science Team Algorithm Theoretical Basis Document.

Carretta J.V., Taylor B.L., Chivers S.J. 2001. Abundance and depth distribution of harbour porpoise (Phocoena phocoena) in northern California determined from a 1995 ship survey. Fish. Bull. 99:29-39.

Chashchin A.K. 1996. The Black Sea populations of anchovy. Sci. 
Mar. 60: 219-225.

D’Amico A., Bergamasco A., Zanasca P., et al. 2003. Qualitative correlation of marine mammals with physical and biological parameters in the Ligurian Sea. IEEE J. Ocean. Eng. 28: 29-43 https://doi.org/10.1109/JOE.2002.808206

Daskalov G.M. 2003. Long-term changes in fish abundance and environmental indices in the Black Sea. Mar. Ecol. Prog. Ser. 255: $259-270$ https://doi.org/10.3354/meps 255259

Daskalov G.M., Grishin A.N., Rodionov S., et al. 2007. Trophic cascades triggered by overfishing reveal possible mechanisms of ecosystem regime shifts. Proc. Natl. Acad. Sci. USA 104: 10518-10523. https://doi.org/10.1073/pnas.0701100104

De Stephanis R., Cornulier T., Verborgh P., et al. 2008. Summer spatial distribution of cetaceans in the Strait of Gibraltar in relation to the oceanographic context. Mar. Ecol. Prog. Ser. 353: 275-288. https://doi.org/10.3354/meps07164

Dede A., Tonay A.M. 2010. Cetacean sightings in the Western Black Sea in autumn 2007. J. Environ. Prot. Ecol. 11: 1491-1494.

Embling C.B., Gillibrand P.A., Gordon J., et al. 2010. Using habitat models to identify suitable sites for marine protected areas for harbour porpoises (Phocoena phocoena). Biol. Conserv. 143: 267-279. https://doi.org/10.1016/j.biocon.2009.09.005

Eremeev V.N., Zuyev G.V. 2007. Commercial Fishery Impact on the Modern Black Sea Ecosystem: A Review. Turkish J. Fish. Aquat. Sci. 82: 75-82.

Esteban R., Verborgh P., Gauffier P., et al. 2013. Identifying key habitat and seasonal patterns of a critically endangered population of killer whales. J. Mar. Biol. Assoc. UK 94: 1-9.

Evans P.G.H. 1980. Cetaceans in British waters. Mamm. Rev. 10: $1-52$. https://doi.org/10.1111/j.1365-2907.1980.tb00232.x

Evans P.G.H. 1987. The Natural History of Whales and Dolphins. Christopher Helm, London, UK, pp. 343

Ferrero R.C., Walker W.A. 1995. Growth and reproduction of the common dolphin, Delphinus delphis Lineaus, in the offshore waters of the North Pacific Ocean. Fish. Bull. (Wash DC) 93: 483-494.

Fiedler P.C., Reilly S.B. 1994. Interannual variability of dolphin habitats in the eastern tropical Pacific. I. Research vessel surveys, 1986-1990. Fish. Bull. 92: 434-450.

Fontaine M.C., Snirc A., Frantzis A., et al. 2012. History of expansion and anthropogenic collapse in a top marine predator of the Black Sea estimated from genetic data. Proc. Natl. Acad. Sci. USA 109: E2569-2576. https://doi.org/10.1073/pnas.1201258109

Forcada J., Aguilar A., Evans P.G.H., et al. 1990. Distribution of common and striped dolphins in the temperate waters of the eastern North Atlantic. European Research on Cetaceans, 4 64-66.

Forney K.A. 2000. Environmental Models of Cetacean Abundance: Reducing Uncertainty in Population Trends. Conserv. Biol. 14: 1271-1286. https://doi.org/10.1046/j.1523-1739.2000.99412.x

Frantzis A., Gordon J., Hassidis G., et al. 2001. The enigma of harbour porpoise presence in the Mediterranean Sea. Mar. Mammal Sci. 17: 937-943 https://doi.org/10.1111/j.1748-7692.2001.tb01307.x

Gaskin D.E. 1982. The Ecology of Whales and Dolphins. Heinemann Educational Books Inc, London, $459 \mathrm{pp}$.

Gladilina E., Gol'din P.E. 2014. New Prey Fishes in Diet of Black Sea Bottlenose Dolphins "Tursiops truncatus" (Mammalia, Cetacea). Vestn. Zool. 48: 83-92. https://doi.org/10.2478/vzoo-2014-0009

Gol'din E.B., Gol'din P.E. 2004. Observations of cetaceans in the Calamita Gulf (Black Sea) and the adjoining sea area. In: Db V.M. (ed) Marine Mammals of the Holartic. Collection of Scientific Papers. KMK Scientific Press, Moscow, pp. 163-167.

Hamazaki T. 2002. Spatiotemporal prediction models of cetacean habitats in the mid-western north Atlantic Ocean (from Cape Hatteras, North Carolina, U.S.A. to Nova Scotia, Canada). Mar. Mammal Sci. 18: 920-939. https://doi.org/10.1111/j.1748-7692.2002.tb01082.x

Hammond P. S., Macleod K., Berggren P., et al. 2013. Cetacean abundance and distribution in European Atlantic shelf waters to inform conservation and management. Biol. Conserv. 164 107-122. https://doi.org/10.1016/j.biocon.2013.04.010

Hastie T., Tibshirani R. 1990. Generalized additive models. Monogr. Stat. Appl. Probab., 43 pp.

Hastie G.D., Wilson B., Wilson L.J., et al. 2004. Functional mechanisms underlying cetacean distribution patterns: hotspots for bottlenose dolphins are linked to foraging. Mar. Biol. 144: 397-403. https://doi.org/10.1007/s00227-003-1195-4

Ingram S.N., Rogan E. 2002. Identifying critical areas and habitat preferences of bottlenose dolphins Tursiops truncatus. Mar. Ecol. Prog. Ser. 244: 247-255. https://doi.org/10.3354/meps244247

Isojunno S., Matthiopoulos J., Evans P.G.H. 2012. Harbour porpoise habitat preferences: robust spatio-temporal inferences from opportunistic data. Mar. Ecol. Prog. Ser. 448: 155-170. https://doi.org/10.3354/meps09415

Jefferson T.A., Webber M.A., Pitman R.L. 2008. Marine Mammals of the World. A Comprehensive Guide to their Identification. Academic Press, London, 616 pp.

Jefferson T.A., Fertl D., Bolaños-Jiménez J., et al. 2009. Distribution of common dolphins (Delphinus spp.) in the western Atlantic Ocean: A critical re-examination. Mar. Biol. 156: 1109-1124. https://doi.org/10.1007/s00227-009-1152-y

Kaschner K., Quick N.J., Jewell R., et al. 2012. Global coverage of cetacean line-transect surveys: status quo, data gaps and future challenges. PLoS One 7: e44075. https://doi.org/10.1371/journal.pone.0044075

Kenney R.D., Scott G.P., Thompson T.J., et al. 1995. Estimates of prey consumption and trophic impacts of cetaceans in the USA northeast continental shelf ecosystem. J. Northwest Atl. Fish. Sci. 22: $155-171$ https://doi.org/10.2960/J.v22.a13

Kideys A.E. 2002. Fall and Rise of the Black Sea Ecosystem. Science 297: 1482-1484. https://doi.org/10.1126/science.1073002

Kleinenberg K.E. 1956. Mammals of the Black and Azov Seas: Research Experience for Biology and Hunting. USSR Acad. Science Publ. House, Moscow, 288 pp. (In Russian).

Klinowska M. 1991. Dolphins, Porpoises and Whales of the World. The IUCN Red Data Book. IUCN, Gland and Cambridge, 429 pp.

Krivokhizhin S., Birkun A.J. 2006. Offshore gathering of harbour porpoises in the central Black Sea: is it a norm or exception? FINS (the Newsl. ACCOBAMS) 2:2(2): 14-17.

Kuznetsov V.B. 2004. Fluctuations of dolphins' abundance in northern and north-eastern parts of the Black Sea according to polling data (1995-2003). In: Db V.M. (ed) Marine Mammals of the Holartic, Collection of Scientific Papers. KMK Scientific Press, Moscow, pp. 308-310.

Leatherwood S., Reeves R.R. 1990. The Bottlenose Dolphin. Academic Press, San Diego, 653 pp.

Mikhalev Y.A. 2004. The Black Sea bottlenose dolphin (Tursiops truncatus, Montagu, 1821) distribution pattern according to aerial survey data. In: Belkovich V.M. (ed.) Marine Mammals of the Holartic. Collection of Scientific Papers. KMK Scientific Press, Moscow, pp. 397-402.

Mikhalev Y.A., Savusin V.P., Bushuev S.G. 2004. Associated connection between the accumulations of fishes and dolphins in the Black Sea according to the data of aerial surveys. In: Belkovich V.M. (ed) Marine Mammals of the Holartic, Collection of Scientific Papers. KMK Scientific Press, Moscow, pp. 393-397.

Miokovic D., Kovacic D., Pribanic S. 1999. Stomach content analysis of one bottlenose dophin (Tursiops truncatus, Montagu 1821) from the Adriatic Sea. Natura Croatica 8: 61-65.

Moura A.E., Sillero N., Rodrigues A. 2012. Common dolphin (Delphinus delphis) habitat preferences using data from two platforms of opportunity. Acta Oecol. 38: 24-32. https://doi.oro/10.1016/j.actao.2011.08.006

Notarbartolo di Sciara G., Venturino M.C., Zanardelli M., et al. 1993. Cetaceans in the central Mediterranean Sea: distribution and sighting frequencies. Boll. Zool. 60: 131-138. https://doi.org/10.1080/11250009309355800

Notarbartolo di Sciara G., Lauriano G., Pierantonio N., et al. 2015. The Devil We Don't Know: Investigating Habitat and Abundance of Endangered Giant Devil Rays in the North-Western Mediterranean Sea. PLoS ONE 10: e0141189. https://doi.org/10.1371/journal.pone.0141189

Nøttestad L. Sivle L.D., Krafft B A, et al. 2014. Prey selection of offshore killer whales Orcinus orca in the Northeast Atlantic in late summer: Spatial associations with mackerel. Mar. Ecol. Prog. Ser. 499: 275-283. 
https://doi.org/10.3354/meps 10638

Oğuz T, Öztürk B. 2011. Mechanisms impeding natural Mediterranization process of Black Sea fauna. J. Black Sea/Mediterranean Environ. 17: 234-253.

Oğuz T., Malanotte-Rizzoli P., Aubrey D. 1995. Wind and thermohaline circulation of the Black Sea driven by yearly mean climatological forcing. J. Geophys. Res. Ocean. 100: 6845-6863. https://doi.org/10.1029/95JC00022

Ozsoy E., Unluata U. 1997. Oceanography of the Black Sea: a review of some recent results. Earth-Sci. Rev. 42: 231-272. https://doi.org/10.1016/S0012-8252(97)81859-4

Öztürk B. 2013. Some remarks of Illegal , Unreported and Unregulated (IUU) fishing in Turkish part of the Black Sea. J. Black Sea/Mediterranean Environ. 19: 256-267.

Öztürk B., Öztürk A.A. 2002. Status of the cetaceans in the Turkish Black Sea and the Turkish straits system (the Istanbul Strait, Marmara Sea and Canakkale Strait). Report of the International Whaling Commission SC/55/SM2.

Öztürk B., Unsal N., Altug G. 2006. Final Report of Feedback Monitoring Program on the Cyclic Fish Migration through Bosphorus within the Frame of Marine Works to be Carried out in the Marmora Project. Istanbul, Turkey.

Radu G., Anton E., Golumbeanu M., et al. 2011. State of the Main Black Sea Commercial Fish Species Correlated with the Ecological Conditions and Fishing Effort. J. Environ. Prot. Ecol. 12: 549-557.

Radu G., Anton E., Nenciu M., et al. 2013. Distribution and Abundance of Cetacean in the Romanian Marine Area. Cercet. Mar. 43: 320-341.

Raum-Suryan K.L., Harvey J.T. 1998. Distribution and abundance of and habitat use by harbour porpoise, Phocoena phocoena, off the northern San Jaun Islands, Washington. Fish. Bull. (Wash DC) 96: 808-822.

Raykov V.S., Panayotova M. 2012. Cetacean Sightings of the Bulgarian Black Sea Coast over the Period 2006-2010. J. Environ. Prot. Ecol. 13: 1824-1835.

Read A.J., Westgate A.J. 1997. Monitoring the movements of harbour porpoises (Phocoena phocoena) with satellite telemetry. Mar. Biol. 130: 315-322. https://doi.org/10.1007/s002270050251

Reid J.B., Evans P.G.H., Northridge S.P. 2003. Atlas of cetacean distribution in north-west European waters. JNCC, Peterborough, $76 \mathrm{pp}$.

Redfern J.V., Ferguson M.C., Becker E.A., et al. 2006. Techniques for cetacean-habitat modeling. Mar. Ecol. Prog. Ser. 310: 271-295. https://doi.org/10.3354/meps310271

Reilly S.B. 1990. Seasonal changes in distribution and habitat differences among dolphins in the eastern tropical Pacific. Mar. Ecol. Prog. Ser. 66: 1-11. https://doi.org/10.3354/meps066001

Santos M.B., Pierce G.J., López Barreiro A., et al. 1996. Diets of small cetaceans stranded NW Spain. ICES, C.M. 1994/N:11.

Santos M.B., Fernandez R., López A., et al. 2007a. Variability in the diet of bottlenose dolphin, Tursiops truncatus, in Galician waters, north-western Spain, 1990-2005. J. Mar. Biol. Assoc. UK 87: 231-241. https://doi.org/10.1017/S0025315407055233

Santos M. E., Coniglione C., Louro S. 2007b. Feeding behaviour of the bottlenose dolphin, Tursiops truncatus (Montagu, 1821) in the Sado estuary, Portugal, and a review of its prey species. Rev. Bras. Zoo. 9: 31-39.

Sahin C. Hacimurtazaoğlu N. 2013. Abundance and distribution of eggs and larvae of anchovy (Engraulis encrasicolus, Linnaeus, 1758) and horse mackerel (Trachurus mediterraneus, Stein- dachner, 1868) on the coasts of the eastern Black Sea, Turkish J. Zool. 37: 773-781.

https://doi.org/10.3906/zoo-1212-31

Satilmis H.H., Gordina A.D., Bat L., et al. 2003. Seasonal distribution of fish eggs and larvae off sinop (the southern Black Sea) in 1999-2000. Acta Oecol. 24: S275-S280. https://doi.org/10.1016/S1146-609X(03)00022-5

Shapiro G.I., Aleynik D.L., Mee L.D. 2010. Long term trends in the sea surface temperature of the Black Sea. Ocean Sci., 6: 491-501. https://doi.org/10.5194/os-6-491-2010

Smith T.D. 1982. Current understanding of the status of small cetacean populations in the Black Sea. In: Mammals in the sea. FAO Fisheries Series, pp. 121-130.

Stockwell D. 1999. The GARP modelling system: problems and solutions to automated spatial prediction. Int. J. Geogrf. Inf. Sci. 13: 143-158. https://doi.org/10.1080/136588199241391

Tonay A., Öztürk B. 2003. Cetacean bycatches in turbot fishery on the western coast of the Turkish Black Sea. In: Int. Symp. Fish. Zool., Istanbul, Istanbul University, Faculty of Fisheries, 8 pp.

Tonay A., Oztürk A.A. 2012. Historical records of cetacean fishery in the Turkish seas. J. Black Sea/Mediterranean Environ. 18: 388-399.

Tonay A., Dede A., Öztürk A.A., et al. 2007. Stomach content of harbour porpoises (Phocoena phocoena) from the Turkish Western Black Sea in spring and early summer. Rapp. Comm. Int. Mer Mediterranée 38.

Torres L.G., Read A.J., Halpin P. 2008. Fine-scale habitat modeling of a top marine predator: do prey data improve predictive capacity? Ecol. Appl. 18: 1702-1717. https://doi.org/10.1890/07-1455.

UNEP 1996. State of the marine and coastal environment in the Mediterranean region. MAP Technical Report Series No. 100. Athens: UNEP.

Van der Wal J., Shoo L., Januchowski S. 2010. SDMTools: Species Distribution Modelling Tools: tools for processing data associated with species distribution modelling exercises. R Packag version 1.

Watts P., Gaskin D. 1985. Habitat index analysis of the harbour porpoise (Phocoena phocoena) in the southern Bay of Fundy, Canada. J. Mammal 66: 733-744. https://doi.org/10.2307/1380800

Wood S.N. 2001. mgcv: GAMs and Generalized Ridge Regression for R. News 1: 20-25.

Wood S.N. 2006. On confidence intervals for generalized additive models based on penalized regression splines. Australian and New Zealand. J. Statistics 48: 445-464. https://doi.org/10.1111/j.1467-842X.2006.00450.x

Young D.D., Cockcroft V.G. 1994. Diet of common dolphins (Delphinus delphis) off the south-east coast of southern Africa: opportunism or specialization? J. Zool. 234: 41-53. https://doi.org/10.1111/j.1469-7998.1994.tb06055.x

Zaitsev Y., Mamaev V. 1997. Biological diversity in the Black Sea: A study of change and decline. United Nations Publishers, New York, 208 pp.

Zemsky V. 1994. History of the Russian fishery of dolphins in the Black Sea. In: Proceedings of the First International Symposium on the Marine Mammals of the Black Sea (Istanbul, Turkey, 27-30 Jun 1994). ACAR Matbaacilik AS, Istanbul, Turkey, pp. 46-48.

Zuur A.F., Ieno E.N., Elphick C.S. 2010. A protocol for data exploration to avoid common statistical problems. Methods Ecol. Evol. 1: 3-14 https://doi.org/10.1111/j.2041-210X.2009.00001.x 